\title{
Beyond Legalism in Turbulent Times: Re-grounding UK Social Work in a Richer International Human Rights Perspective
}

\author{
María Inés Martínez Herrero ${ }^{1}$ (D) J Jack Nicholls ${ }^{1}$
}

Published online: 22 August 2017

(C) Springer International Publishing AG 2017

\begin{abstract}
Human rights have always been intrinsically woven into social work, but in the UK, often in a way that is either vague or wholly legalistic. In this article, we make a case for embedding a broader and richer concept of human rights in UK social work practice and education. We contrast the international social work perspective on human rights with that of UK professional codes and suggest that the narrow and uninterrogated conceptualisation of human rights in the UK may be acting as a barrier to UK social workers fully understanding and engaging with broader human rights agendas of the sort found in international practice. We argue for the merits of regrounding UK social work in this broader human rights concept, in which radical and emancipatory approaches can be underpinned by a common and unifying rights-orientated perspective. We make this argument, initially, in the context of the Human Rights Act 1998 remaining in UK law, which we see as entirely necessary for the protection of human rights in social work in the country, but insufficient for a broader, richer concept. We also, however, consider a scenario in which the Act is replaced by a British Bill of Rights and argue that such a development would present a further urgent need for embedding a broader human rights concept in UK social work. We close by setting out some of what such a concept might involve.
\end{abstract}

Keywords Human rights · Social work · Human Rights Act · Legalism $\cdot$ International social work $\cdot$ UK

María Inés Martínez Herrero

maria.martinez@northumbria.ac.uk

1 Department of Social Work, Education and Community Wellbeing, Coach Lane Campus East, Northumbria University, Room G214, Newcastle Upon Tyne NE7 7XA, UK

\section{Introduction}

\section{Human Rights in Social Work}

International organisations of social work claim that social work is 'a human rights profession' (IFSW-Europe 2012: 5; Wronka and Staub-Bernasconi 2012: 70). Social work's human rights roles, it is argued, derive from a dual mission of assisting the particular needs of individuals, families and communities whilst seeking the development of fairer social structures (IFSW-Europe 2012), upholding people's dignity, security and development (IFSW 1988). Such broad concepts of human rights in international social work contrast with their conceptualisation in UK codes of practice, which we argue are at some points reductionist and legalistic, at others vague. We argue that conceptualisations of human rights in UK social work, where not vague, largely revolve around a compliance with the legal requirements of the UK Human Rights Act 1998 (which establishes human rights of a civil and political nature) (Great Britain. Elizabeth 11. Chapter 42 1998) and rarely envisage broader, non-legalistic perspectives.

\section{Our Aims in this Article}

In this article, we seek to contrast UK and international perspectives and make a case for a broader, richer concept of human rights in UK social work practice. We suggest that the present narrow UK conceptualisation of human rights may be acting as a barrier and preventing UK social work practitioners and educators from fully engaging with the broader human rights agendas of social work international organisations and with human rights-based social work practice models developing in other European countries and other parts of the world (Lorenz 2016; Higgins 2015). We argue therefore that the UK profession would benefit from a more 
enriched understanding of human rights to underpin social work values and practice, particularly in current national and international circumstances.

We make this argument, in the first instance, in the context of the Human Rights Act 1998 (HRA 1998) remaining in UK law, which we see as necessary for the protection of human rights in UK social work, but insufficient for a broader, richer concept. However, the recent general election in the UK resulted in the Conservative Party continuing in government. The Conservatives have in successive manifestos variously pledged both reconsideration and outright replacement of the HRA 1998, and their present minority government status does not, in our view, remove the potential for the legal protections of the Act being loosened. We argue that this increases the urgency of enriching the human rights concept in the social work professional consciousness. We end with some discussion about what this concept might look like.

\section{Our Approach}

The literature-based research underpinning this article consisted of a review of existing social work literature on international approaches to human rights, and analysis of how the main codes that govern UK social work conceptualise human rights considerations. We looked specifically at the Code of Ethics of the British Association of Social Workers (BASW), and the differing standards/practice guidance codes that govern social work in England, Northern Ireland, Scotland and Wales. We looked at the references made to human rights in the body of each code, examining how the term was used, and what expectations on social workers to practice in a human rights-informed/compatible way looked like. These documents represent, in our view, the primary source of guidance which students and practitioners refer back to, and this was the rationale for focussing on them. We also examined the 2017 manifestos of the four main parties in the UK and, given the brevity and vagueness of the Human Rights policy in the 2017 Conservative Party Manifesto (the present party of government) scrutinised a human rights policy document published by the party, before the 2015 UK general election looking at areas of incompatibility with social work values and broader human rights positions.

Ultimately, this research was informed and motivated by our insights on the topic, which draw from our experiences as qualified social workers (trained in Spain and England, respectively) and from our experiences as social work lecturers in England, as well as from our previous research on human rights and social justice related topics in social work (e.g. Martínez Herrero 2017).

We believe this article offers an informed, relevant and timely discussion around how human rights are understood vis-à-vis the role of UK social workers in rapidly changing contexts, which is impacting directly on key social work professional values. We believe this offers a valuable resource for bridging an understanding of human rights concepts and developments outside and within the UK, promoting in the latter richer understanding and practice mentality regarding human rights-based social work. Notwithstanding these contributions, we acknowledge that the arguments we put forward are literature and opinion-based. These could be further corroborated, or questioned, by future empirical research on the topic from different stakeholders of UK social work. We keenly encourage such research.

\section{Social Work as a Human Rights Profession}

Social work is claimed as a 'human rights profession' (IFSWEurope 2012: 5; Wronka and Staub-Bernasconi 2012: 70) with a human rights tradition 'of more than 100 years', which is, however, 'mostly unknown' (Staub-Bernasconi 2016: 40). Early social work founders and leaders, at the end of the nineteenth century, were involved in human rights movements and international human rights organisations such as the League of Nations, the Red Cross or Save the Children (Healy 2008; Reichert 2003). And there are many documented accounts throughout social work's history of involvement with human rights activism across the world. This includes involvement in the US Civil Rights movement, antiapartheid movement in South Africa, the non-violent tradition of Gandhi or campaigns for the indigenous people's rights (Ife 2016; Staub-Bernasconi 2016; Healy 2008). Moreover, there are incontestable similarities between social work's mission and values and human rights language and discourses, as reflected in worldwide social work codes of ethics, official statements and theoretical developments (Healy 2008; Banks 2006; Reichert 2003). However, this fundamental relationship has tended to be implicit and at times transgressed and ignored by social work (Ferguson et al. 2017, forthcoming; Ioakimidis 2015; Dominelli 2012; Lee 2011; Lundy 2011; Dominelli 2010; Ferguson 2008; Payne 2005; Finn and Jacobson 2003).

In more recent years, human rights perspectives are gaining prominence in the statements of international social work organisations (Jones and Truell 2015; IFSW and IASSW 2014; IFSW-Europe 2012; Sewpaul and Jones 2005; IASSW and IFSW 2004; IFSW 2000) and social work theory internationally; many are claiming that the coupled principles of social justice and human rights enable the profession to face the challenges brought about by neoliberal capitalism and globalisation (e.g. Huegler et al. 2012; Staub-Bernasconi 2011; Ife 2008). These challenges link with social problems deriving from increasing inequalities, poverty, social exclusions and cultural and religious conflicts and violence (Sewpaul 2016). Sewpaul (2016: 32) has recently highlighted how, 'within the [global] neoliberal framework' 
social and economic exclusions are fostered by the process of othering, based on criteria such as "race", religion, ethnicity, nationality, sexuality and gender, and refugees and asylum seekers are deemed to be the undeserving other, which is accentuated in the existing climate of global terrorism and Islamophobia

In this global context, it is argued, human rights offer a unique discourse for strengthening and unifying the profession under a common framework which empahasizes individual rights, the elimination of discrimination and humane, sustainable development of societies towards greater social justice (IFSW and IASSW 2014; IASSW and IFSW 2004; Ife 2008; Staub-Bernasconi 2011). The International Association of Schools of Social Work (IASSW) and the International Federation of Social Workers (IFSW) (IASSW and IFSW 2014) claim that 'advocating and upholding human rights and social justice is the motivation and justification for social work'. This assertion is part of the commentary notes of the 2014 International Definition of Social Work and can be seen as a political statement in its own right, involving a distinctiveness claim from other caring and social professions.

Thus, a human rights approach can work on two levels; repositioning social work as a human rights profession allows it to be seen as having a particular role to play in fulfilling the worldwide collective struggle for human rights and social justice (i.e. it joins, in a full way, the pantheon of human rights disciplines, professions and social movements) (Ife 2016, 2008). It also strengthens and links different emancipatory models of practice under a common framework (Cemlyn 2008b; Ife 2008; Méndez Fernández et al. 2006; Reichert 2003). However, to do so, the human rights concept needs to be fleshed out beyond the legalistic, negative rights concept.

\section{International Social Work Perspectives on Human Rights}

Worldwide, human rights are most commonly associated with the United Nations human rights machinery, built upon the United Nations Universal Declaration of Human Rights of 1948 (UDHR). The UDHR defines human rights as inalienable rights belonging to every person for the fact of being human. These are rights and freedoms that allow us to satisfy fundamental human needs and which 'set the foundation of freedom, justice and peace in the world' (United Nations 1949: para.1). The human rights established by the UDHR included civil, political, economic, social and cultural rights and reflected the commitment of countries across the world to settle the basis of a world order in which the contemporaneously recent horrors of World War II and the Nazi Holocaust could not be repeated and poverty was alleviated (Ife 2009,
2008; Dominelli 2007; Finn and Jacobson 2003; Reichert 2003; United Nations 1994, 1949).

Although the UDHR emphasises the interdependence and indivisibility of all human rights, analyses of the Declaration commonly divide these rights into three sets or generations:

1) A first set of negative rights relating to political and individual freedoms that restrict governments' roles and conduct towards citizens;

2) A second set of positive rights that ensure governments seek to grant all citizens the best living standards the resources of the countries allow;

3) A third set of collective rights that requires the solidarity and cooperation among nations on global issues and development.

The commentary notes of the international definition of social work (IFSW and IASSW 2014: para.8) assert that 'Social work embraces first, second and third generation rights'. A strictly legalistic understanding of human rights in UK social work, however, focuses exclusively on the compliance in practice with the first-generation civil and political rights enshrined in the HRA 1998, preventing an understanding of second and third-generation human rights issues from being incorporated within a human rights-based practice framework in the profession.

From the broader view of human rights' role in the social work profession promoted by the IFSW and IASSW (IASSW) (2014, 2004), the current compartmentalisation of human rights in UK social work is problematic as it is inconsistent with the UDHR-based principles of interdependence and indivisibility of human rights. This individualist legal understanding of human rights arguably reflects Western biases in which individualised civil and political rights are deemed a priority against social, cultural and collective rights (Evans and Ayers 2006).

Much of the theoretical focus in international social work currently lies in the development of social work's broader, relationship-based understanding of the human rights involved in the social problems of clients. From this perspective, Ife (2016: 7), for instance, appeals for social workers to go beyond such legalistic approaches and engage with human rights narratives 'based on relation-ship, on human rights as collective, and as social' and which have the potential to form the basis for daily practices of professional social work and to enhance social work's transformative potential.

\section{Human Rights in UK Social Work Codes}

In Western social work, there has been a dominance of legalism-based understandings of human rights, deriving from 
European Enlightenment and UN developments of human rights instruments and law (Ife 2016). This appears to be very much the case for social work in the UK, where the understanding of human rights tends to be confined to civil and political rights enshrined in the European Convention on Human Rights and Fundamental Freedoms (ECHR) and incorporated in UK domestic legislation with the HRA 1998. The Equality and Human Rights Commission of the United Kingdom (EHRC), for example, defines human rights from a legalistic perspective as fundamental rights and freedoms of any person in the world, but which 'are not just abstract concepts - they are defined and protected by law' (EHRC 2016: para.2).

Social work is since 2001 , a statutory regulated profession in the UK, which has been subject in the last decade to continuous and ongoing reviews and reforms (Cromarty 2016). Social work regulation competencies are a devolved matter; hence, there are independent regulators (referred to as Councils) for social work in England, Northern Ireland, Scotland and Wales. The written standing of human rights in UK social work codes of practice, ethics and professional identity varies. In some places, the implication is that they rest on a legalistic understanding of human rights, and in others, the sense is much more general, but ill-defined. Primarily, however, what is striking is the lack of clarity and definition of exactly what human rights should look like, in UK social work.

The social work Professional Capabilities Framework (PCF) for England (BASW 2017) is the overarching framework of professional standards in social work practice in England, which is split into nine domains and identifies expected levels of capability from becoming a social work student to becoming a Principal Social Worker. The PCF explicitly mentions human rights in Domains 2 and 4 (addressing 'Values and Ethics' and 'Rights, Justice and Economic Wellbeing,' respectively). Experienced social workers are required to apply 'professional ethical principles to decisionmaking and practice, supporting others to do so using a legal and human rights framework', as well as to 'advance human rights and promote social justice and economic wellbeing'. They are also expected to 'recognise the fundamental principles of human rights and equality ... (which are) ... protected in national and international law, conventions and policies', and to 'model best practice in applying human and civil rights, providing support to others and challenge where required' (BASW 2017: 3). This does not provide much clarity around the understanding of human rights that the PCF seeks to advance for practitioners; there is one semi-explicit reference to human rights as a legally protected concept and another as a framework (alongside 'legal' frameworks rather than being an example of a legal framework itself). In other places, however, the code places human rights alongside equality, social justice, economic wellbeing and civil rights, which suggests those concepts are connected to, but distinct from, human rights. This vagueness of commitment is not a new issue; Cemlyn (2008a) makes similar criticisms of the forerunner to the PCF, the general social care council codes of practice 2006 (GSCC 2006).

The main codes and guidance for practice from Scotland, Wales and Northern Ireland make reference to human rights and to the HRA in places, but generally, these documents are vague and unspecific, or legalistic, in their interpretation of human rights and the Act. There are also multiple references in all documents to rights more generally that arguably fit with social work values in a broader sense, though these rights are not always set out explicitly.

In terms of vague references to human rights, the revised social work standards for Scotland (SSSC 2016) have no specific references to human rights, despite the report from those involved in revising those standards (Daniel et al. 2016), opening with reference to the England PCF's Domain 4 that social workers should 'advance human rights and promote social justice' (p. 9). The practice guidance for social workers in Wales (Social Care Wales 2017) and the Northern Ireland Standards of Conduct and Practice (NISCC 2015) both open with preambles based on the international definitions of social work, which state that principles of social justice and human rights are fundamental for the profession. The Northern Irish standards also include a requirement for social workers to support 'Rights: the entitlements that individuals have legally, socially and ethically, including human rights' (p. 39) but does not here specify which of those categories human rights belong to.

In terms of legalism and reductionist references to human rights specifically as legislation, the Wales standards of practice (Social Care Wales 2017) require practitioners to "familiarise (them) self and comply with organisational policies and procedures' (p. 11) in which they include the 'Human Rights Act 1998, and associated...protocols' including UN rights conventions and British legislation (p. 11-12). The Wales guidance also refers readers to the Equalities and Human Rights Commission.

There is one specific exception to the vagueness and legalism around human rights that characterises the UK codes; section 7 of the Wales practice guidance (Social Care Wales 2017) states that the 'Human Rights Act 1998 applies to children and young people and adults... If you are working with children and young people, it is essential that you fully recognise their distinct needs and specific rights that may be different to those that apply to adults' (p. 10). The standards, citing the UN Convention on the Rights of the Child (UNCRC), establishes 'core aims' which include 'hav(ing) a comprehensive range of education and learning opportunities', '....a safe home and a community which supports physical and emotional well-being', 'enjoy the best possible health and not being' and '...not disadvantaged by poverty' (p. 10). We interpret these aims as 
having inherent aspects of positive, second-generation human rights, possibly because as well as the HRA, they draw on the UNCRC which we argue is more aligned with positive rights.

The British Association of Social Workers (BASW) Code of Ethics, applicable to the four UK nations, initially lists human rights as a value (drawing from the 2000 International Definition of Social Work (IFSW 2000)) again alongside social justice and professional integrity. It places 'respect for human rights and a commitment to promoting social justice' at 'the core of social work practice' and describes both as 'motivation and justification for social work action' (BASW 2014: 5). The BASW code makes reference to the UNDHR and says practitioners should use authority in accordance with human rights principles. The code also exhorts practitioners to challenge abuse of human rights, challenging 'discriminatory, ineffective and unjust policies, procedures and practice', as well as to not colluding with the erosion of human rights (examples given include systematic abuse, detention of child asylum seekers and threats to family life of those in vulnerable positions) (BASW 2014: 14). Neither the PCF nor the BASW Code of Ethics makes any distinction, explicitly, between negative, positive and collective (or first, second and third generation) rights. In defence of BASW, they recognise in a later published Human Rights Policy that the legalistic and narrow understanding of human rights in UK social work is the most pervasive one, asserting that 'human rights as they have been passed into legislation in the UK have often been given a narrower meaning than the understanding social workers have as a profession' (BASW 2015: 4).

The 2017 Health and Care Professions Council (HCPC) standards for social workers in England does not explicitly mention human rights at all, and even as regards 'rights' more general, includes only the 'need' (rather than, say, duty) to 'respect and so far as possible uphold, the rights ... of every service user and carer' (HCPC 2017: 9), 'to assist (service users) to understand and exercise their rights' and 'be able to support service users' and carers' rights to control their lives (HCPC 2017: 10). The focus, we argue, from the HCPC is on the practicable and empowerment of the client to uphold their own rights, quite distinct from the language of universalism and positive or collective rights. From these sources, we are no closer to a clear view on the concept of human rights advanced in the core codes of UK social work.

In arguing that the conceptualisation of human rights in UK social work codes are generally either vague or legalistic, it is worth pointing out that the codes examined make multiple reference to human welfare, economic wellbeing, justice, equality and an enabling rather than restrictive application of law. For instance, in the BASW code, we find the assertion that

Social work grew out of humanitarian and democratic ideals, and its values are based on respect for the equality, worth, and dignity of all people. Since its beginnings over a century ago, social work practice has focused on meeting human needs and developing human potential (BASW 2014: 5).

All of these could fit into a wider second or thirdgeneration human rights concept, yet in UK social work, they are not so labelled or categorised. The challenge may be not in searching UK social work values for implicit human rights commitments (in principle if not always in action) but in getting them as understood as being human rights commitments explicitly. We argue that this kind of understanding of human rights in UK social work has led to the focus being on the legal processes, rather than on the wider ethical concept. We are advocating a rebalancing of that trend, for several reasons.

The first argument is concerned with where the moral focal point of the social work profession presently lies. Social work values contained in the codes which we have referred to are necessary and legitimate, but when conceptualised as values rather than also as rights, they unconsciously reside in the category of expectations upon the worker rather than also as the entitlements of the client, carer, family or community. Clark (2006) has argued that more attention should be paid to the moral positions of social workers, on the basis that the profession currently takes value-neutral position on human welfare and the good life. He argues that social workers should demonstrate virtuous character, and while we agree to a point, we also argue that the focus of what needs to change should go beyond (though still include) the practitioner's mentality. If considered as part of a broader human rights concept, the expectation subtly but importantly shifts from what the practitioner should believe in, important as that is, to what the client is entitled to. In current circumstances, where social work in the UK is already criticised for becoming increasingly residual and responsibilising, with more services being transferred from state to independent sector (Milbourne and Cushman 2013; Hatton 2008; Ferguson 2007), we argue it would be beneficial to shift the professional mindset from simply concentrating on values that are good for the worker to hold, to being rooted in entitlements and treatment of people, by no other broad qualification than the fact that they are people, that is both good and right.

The second argument is rooted in the re-conceptualisation of UK social work as part of a global profession, which we argue has fallen from the agenda in this country. In the context of the discussions of human rights in social work, Banks (Banks et al. 2008: 288) synthesises, the profession can be considered on two levels; 'necessarily rooted in particular nation states, cultures, and legal and policy frameworks' and as 'an international social movement, concerned to work for social justice worldwide'. Both levels of the profession arguably have strong implications for the human rights concept the profession utilises. Upholding human rights through social work practice at these two levels would require an 
understanding of human rights that involves, but needs to go beyond, a solid knowledge of individual rights (Banks et al. 2008) and 'conventional legal-based human rights narratives for social work' (Ife 2016: 1) enclosed within human rights legalistic approaches. We currently live in an era in which nationalism, inter/intra-cultural social division and debates around borders are on the increase. More needs to be done in social work and society to broaden an ethic of human universality and undifferentiated entitlement not only to minimal rights but to a good life of meaningful opportunity. Given the national and global circumstances in which we find ourselves, we argue that a broader concept of human rights would serve to enable a more meaningful, more deep seated sense of genuine empathy - of genuine attempts to understand the experience and situation of the other, combatting the idea of the other as underserving as articulated by Sewpaul (2016).

\section{The Political Context of the Human Rights Act}

The narrow, legalistic UK conceptualisation of human rights may stem from the way they have been understood in British politics over recent decades. Having been introduced by the 1997-2010 Labour Government, successive Conservative Party leaders have mooted or actively sought repeal or overhaul of the HRA 1998. A Conservative policy paper published ahead of the 2015 UK General Election criticised the Act as being against common sense, open to trivial claims and as against UK parliamentary sovereignty and the ability of the UK state to defend itself (Conservative Party 2014). We should say, clearly, that while neither of us are political conservatives, this paper is not in and of itself a comment on the UK Conservative Party in its own terms, but in its place as the present party of government. That government, elected as a majority in 2015 then reduced to a minority in the 2017 election, has expressed interest in replacing the Act with a British Bill of Rights (House of Commons Library 2016), though they have not as yet made this a legislative priority, initially because of the government's slim then-majority (Swinford 2017) which has now gone. The 2017 Conservative Manifesto was more circumspect on the matter of human rights law, but also more vague, only making provisions around the status quo within the limits of the Brexit negotiations and the next parliament (the latter being of uncertain length at present). It states that

We will not bring the European Union's Charter of Fundamental Rights into UK law. We will not repeal or replace the Human Rights Act while the process of Brexit is underway but we will consider our human rights legal framework when the process of leaving the EU concludes. We will remain signatories to the European Convention on Human Rights for the duration of the next parliament. (Conservative Party Manifesto 2017: 37)
The only other mention in the manifesto is that British troops will be subject to the Law of Armed Conflict, rather than the ECHR (p. 41).

Despite the implicit back-step, this could be argued to represent, we remain concerned that, in the medium term, the Act could be altered or replaced, and this will have profoundly negative consequences for human rights concepts in UK social work.

The replacement of a majority with a minority Conservative government does not to our minds automatically equate to stronger footing for human rights, for several reasons; firstly, the Democratic Unionist Party (DUP), on whom the Conservative government is relying for support, are themselves a Eurosceptic party with conservative views on what are often considered social rights issues, such as abortion and LGBTI rights (Bush 2017). Secondly, following the terror attacks during the election, Conservative rhetoric around amending rights legislation towards the prevention of terror became a recurrent feature of the campaign (BBC News 2017). In the horrific instance of further attacks, it is conceivable that such an agenda may resurface even with a minority government. Thirdly, the now-Prime Minister previously said she favoured withdrawal from the ECHR and would campaign to leave it (Worley 2016). Finally, there is the possibility of a non-conservative government coming to office with or without a further election. The 2017 election manifestos of the other major partiesthe Labour Party, the Scottish National Party and the Liberal Democrats-generally included maintenance of human rights, either in general terms or with reference to the Act and the ECHR, and on the promotion and embedding of human rights in and through trade and international development policy (Labour Party 2017; Liberal Democrats 2017; Scottish National Party 2017). In such an instance, the long standing of the subject of Human Rights law reform in the Conservative party would suggest it would be a policy focus for a future Conservative opposition and then potentially Conservative government. Therefore, in our view, the potential reform or replacement of the HRA 1998 remains pertinent as a concern.

Hitherto, we have argued for a fuller, richer and deeper concept of human rights in social work in current circumstances, in which we retain the HRA 1998 and build upon it. We should, however, consider the position of social work in the very possible future instance of the UK scrapping the Act. In some ways, the profession's position would depend on what the Act was replaced with, but we argue that the legalistic concept and the Human Rights Act 1998 are, if insufficient, nonetheless essential for both the letter and spirit of human rights in UK social work. We make the argument that whatever the replacement, the simple fact of the replacement of the Act will have certain negative effects. 


\section{Implications for Social Work of the UK Replacing the Human Rights Act}

Advocates of scrapping the HRA frequently advance its replacement with a British Bill of Rights. In our view, such a change risks making UK social work's commitment to a broader concept of human rights thinner and weaker, for several reasons. We discuss some of our criticisms, the core points of which are the loss of a sense of universalism of rights and the introduction of differentiated use of rights based on subjectively perceived 'seriousness' of circumstance and on country of birth. We also argue strongly, however, that in a situation in which the HRA is replaced with a British Bill of Rights, it is all the more urgent and important to have a deeper sense of human rights embedded in social work that can survive independently of the Act.

Firstly, there is the symbolism of the withdrawal. The scrapping of the HRA could result in a further blow to the sense of universality of entitlement, including even before the law. Though it is an aspect of practice not often spoken about, this element is particularly important for work with clients that social workers might find personally challenging to work with - parents who have abused their children, people who have been convicted for sexual offences, and individuals who have committed very violent crime. The professional obligation to this kind of equality of treatment will not of course die with the HRA, but the symbolism of scrapping the Act would represent a loss of one of the planks in the continuing mission, not always easy, to treat everyone with a level of basic dignity, at those times where practicality, expediency or even gut instinct absent reflection might impede that value.

This symbolic effect in social work would be occurring in a wider context in which the British public would perceive, rightly or wrongly, that in scrapping the HRA, its government had lessened its commitment to human rights more generally. Social work would be practicing in a society where human rights, already understood as a set of legal obligations rather than a self-sustaining ethical stance, would have been symbolically resiled from by the government. Following the vote to leave the European Union (and this article is not a tract on those proceedings), a well-documented number of racist attacks and protests were recorded by police and the media (BBC News 2016; Forster 2016; Travis 2016). Quite apart from the appalling nature of these instances, they were also based on misunderstanding of the referendum. We refer to this not to make judgements of the referendum, but to argue that changes of this sort have immediate symbolic effects that can be misunderstood, misrepresented and hurriedly acted upon. It will be incumbent upon social workers, per our professional values and ethics, to combat discrimination in an environment where discrimination may have been further legitimised in the popular imagination.

The aforementioned Conservative Party policy paper detailing a proposed replacement of the HRA with a British Bill of Rights (Conservative Party 2014) creates several points of concern for social work. The paper explicitly calls for smaller and more residual remit to focus human rights on 'serious offences', rather than what the proposal calls 'trivial' (Conservative Party 2014: 7). The distinction between what is a serious and what is a trivial issue is unclear and subjective and endangers the standing of wider and richer second or third-generation human rights becoming embedded in social work and society. Social work frequently deals with issues that are both mundane and of vital importance to the client or family. Is the successful provision of a mid-level care package trivial or serious? Is the regularity of respite for a family with a severely disabled child trivial or serious? If the answer is that it depends on the severity of the situation or the severity of the abuse, neglect or harm that has occurred, then recourse to human rights arguments and human rights protection has at a stroke become residualised. Put more plainly, if the HRA is replaced by law only for 'serious' cases, then by definition, these rights are attached specifically to situations when things have gone very wrong, rather than to the spirit of preventative care. There are also concerns that the responsibilities of noncentral government bodies, which could include local authorities and commissioned tax-payer funded independent sector providers, would not be clear under a British Bill of Rights (Stone 2015). These two concerns taken together mean an uncertain situation for the concept of human rights at the level of most social workers' day-to-day practice.

Secondly, the proposal argues for strengthening the link between rights and responsibilities in a British Bill of Rights. This has the potential to set a dangerous precedent-rights linked to responsibilities are, by definition, conditional, and one can lose them by not conforming to those conditions. Whilst many rights enjoyed by UK citizens and visitors, and by social work clients are conditional, it is a fundamental tenet of human rights that they be universal in terms of who by virtue of simply being human (United Nations 1949), even if they are conditional in terms of when or how they are applied. Liberty, a campaigning organisation for fundamental rights and freedoms in the UK (Liberty n. d.), makes the distinction between rights coming with responsibilities and rights that are conditional on the fulfilment of responsibilities. Pending further clarification, the notion of 'strengthening the link' is one that is dangerously vague with regard to the universality of human rights.

Thirdly, and continuing the theme of the risked decay of universal rights, the proposed British Bill makes nationalistic distinctions around who may avail themselves of certain rights. For example;

The Convention recognises that people have civic responsibilities, and allows some of its rights to be restricted to uphold the rights and interests of other people. Our new Bill will clarify these limitations on individual rights in certain circumstances. So for example a foreign 
national who takes the life of another person will not be able to use a defence-based on Article 8 to prevent the state deporting them after they have served their sentence (Conservative Party 2014: 6).

The example given here, of the deportation of a foreign national, is tantamount to a double punishment. Critics of the HRA may say we should not be concerned with the human rights of convicted murderers, but this change coming into force would by definition be entirely concerned with the human rights of a convicted murderer, provided they are Britishborn, because this provision makes a distinction based on country of birth. Therefore, the principle of universalism has been not only been abandoned, it has been replaced by a provision that discriminates by citizenship.

This could be considered an extreme example, but it would set a precedent for country of origin being a factor in who is able to avail themselves of, in this case, Article 8; a distinction which could establish case law for other scenarios. This would by definition represent an erosion of human rights, which social workers are professionally committed to standing against (BASW 2014). Smith (2017) writing on the website 'About Human Rights' suggests that a British Bill of Rights could be a unifying force for the UK citizenry; our concern is that even if so, such unity would be born of nationalist partialism that has no place in UK social work, but that is already on the increase in UK welfare law and politics.

A recurring theme in criticisms of the HRA is the acknowledgement by those who would overhaul it that human rights did not begin with the Act and will not stop being important if it was replaced. We have argued in this paper that there are deficits to legalistic understandings of human rights, but we also argue that the legal concept and the HRA are essential, if insufficient, for both the letter and spirit of human rights in UK social work. Replacing the HRA with a British Bill of Rights would change the relationship between human rights and the social work profession. Social work codes elaborating professional responsibilities wound need to be revised. Critics of the HRA in the UK frequently advance the argument that human rights themselves predate the Act and will not be scrapped simply because the Act itself is (Conservative Party 2014). If, however, the Act is scrapped or replaced, but social work still seeks to embody and pursue human rights in its practice and values, we will need to move on from the legal definition, because it will simply no longer be there to be drawn on in UK law. ${ }^{1}$ It is therefore all the more incumbent upon the caring professions, including social work, to start incorporating and advancing a concept of human rights that

\footnotetext{
${ }^{1}$ It needs to be noted, however, that as far as the UK remains a signatory part of the European Convention on Human Rights and Fundamental Freedoms (ECHR), people in the UK will still be able to take human rights legal cases to the European Court of Human Rights.
}

is closer to the second or third-generation model. As removing general reference, even undefined, to human rights from social work codes would be unthinkable, it would be incumbent upon our profession to spell out our understanding of human rights. At the moment, that understanding, frankly, lacks conceptual clout.

\section{Towards a Broader Understanding of Human Rights in UK Social Work}

We have argued for the embedding of a broader, richer concept of human rights in social work both in potential situations where the UK retains or replaces the Human Rights Act. We seek here to set out some of what that concept might involve.

Central to this argument is the idea that to advocate a broad human rights concept to underpin social work practice is not to propose a completely new paradigm for social work. Many of the building blocks, including many radical and progressive approaches and therapeutic intervention models, are already established in social work thought. In advancing a broader human rights concept for UK social work, we are seeking to draw those progressive approaches together under a human rights perspective that embeds universal rights entitlement across borders, critical consciousness about structures and the regrounding of values in the territory of client rights and opportunities rather than simply as practitioner attributes.

\section{Existing Building Blocks}

The differentiation between narrower and broader understandings of human rights in social work is relevant in the discussions about the theoretical and practice models for human rights-based social work practice, in that a broader understanding means that social workers can utilise the language of rights to support intervention, grassroots and community action and empowerment, whereas a narrower understanding roots human rights concerns purely in the purview of the legal system. Wronka and Staub-Bernasconi (2012: 19) assert that as follows:

For the narrower conception of human rights protection, one needs close cooperation with lawyers; for the broad conception, one can use various social work methods such as resource mobilization, consciousness raising, mediation, and empowerment. More specific methods include using the official instruments of the UN for complaints, monitoring, lobbying, and, more and more, also whistle blowing. But in many cases, one needs civil courage to stand up against actors in a power structure.

From a broad human rights framework embracing the three generations of human rights, any social work theoretical 
foundation or intervention consistent with a dual focus on assisting individuals (and groups) and bringing about social change on broader levels (which the IFSW and IASSW 2014 say social workers, globally, should do), can be safely situated in the terrain of human rights and considered a human rights instrument for guiding social workers' human rights-centred practice (Reichert 2003: 228). In this vein, Cemlyn (2008b: 224-225) highlights the links among human rights and the different 'emancipatory' (literally 'setting free') approaches to social work 'that seek to challenge inequalities at structural and personal levels, promote greater autonomy and empowerment, and resist policies and practices that disempower and oppress'. These approaches may include radical, structural, transformational or anti-oppressive social work (Cemlyn 2008b), culturally sensitive and empowerment and strengthsbased social work (Reichert 2003), humanism (IFSW-Europe 2012), dialogical praxis, feminism, participatory democracy or anti-colonialist practice (Ife 2008) among others. 'A human rights perspective in social work' Cemlyn (2008b: 225) claims 'includes many of these [approaches]' elements: structural critique aiming for liberation from diverse oppressions; involvement and leadership by oppressed people and a reflective and dialogical approach that links personal and collective change'.

\section{Reframing Existing Emancipatory Approaches into a Human Rights Framework}

The Global Standards for social work education (Sewpaul 2005: 3) assert that social workers promote the realisation of human rights through interventions based on practice models and techniques that allow them to pursue a series of 'developmental, protective, preventive and/or therapeutic purposes'. These highlight a series of 'epistemological paradigms' of particular global relevance for the training of social workers that will be prepared to practice according to the professions' commitment with the principles of human rights and social justice (as specified in the 2000 International Definition of Social Work (IFSW 2000)). These include an appreciation of diversity, a focus on capacity building and empowerment in work with individuals, groups, organisations and communities, or an emphasis on advocacy and the promotion of change regarding social structures, which marginalise and exclude people (Sewpaul 2005).

Ife (2008) asserts that social workers can connect human rights with their practice through deductive and inductive approaches. According to Ife, the deductive approaches would involve asking what particular statements and rights mean for practice and then translating these into guiding principles that would lead to a human rights practice. Inductive approaches on the other hand, would depart from practice situations and questioning 'what are the human rights issues at stake' that could inform and enhance practice (Ife 2008: 152). In reality, social workers would use both approaches complementarily, with each informing the other (idea of praxis) (Ife 2008). A paradigmatic shift strengthening the links between broad human rights models and social work practice in the UK would therefore reframe many current social work theoretical models and methods of practice into a human rights framework.

Nonetheless, this would result in more than modified theoretical and practice frameworks. Reframing social work theory and practice models under human rights frameworks would directly bond these with the core social work values of human rights and social justice in a more conceptually coherent and filled-out way. Wronka and Staub-Bernasconi (2012) argue that the ethical bond between human rights and social work involves an additional mandate for the profession to the two classic mandates of care and control. The human rights mandate, they assert, provides the profession with autonomy and 'allows for the modification or refusal of illegitimate claims and mandates from society, social agencies and clients' (Wronka and Staub-Bernasconi 2012: 81). Moreover, it is argued (Ife 2016), moving beyond a merely legalistic understanding of human rights in social work allows for alternative conceptions of a human rights-based social work, which, putting the focus on 'the human' transcend and may question human rights law, let alone nationalistic Bills of Rights.

There are abundant examples of social work models and interventions based on such broader understandings of the human rights role of social work outside the UK. Broad frameworks of human rights have been largely used, for instance, in social work in Spain, where global and Eurozone economic crises and austerity policy responses to those crises, have since 2008 resulted since in a sharp rise in inequality, a marked impoverishment of the population and mass unemployment (Ioakimidis et al. 2014). In this context, a human rights language has characterised the analysis, statements and collective actions of the Spanish National Association of Social Workers (CGTS) facing the socioeconomic crisis in Spain in recent years. For example, during 2015, the CGTS campaigned to raise awareness about social rights violations occurring through public social services cuts, which resulted in the denial of support services for the most vulnerable. This included many activities aimed at mobilising public opinion and political lobbying using human rights language. One of these activities involved support for three Spanish families to denounce in the European Parliament the disgraceful circumstances they found themselves after losing support services, including how this was affecting their children. A documentary about these families called 'Social Rights For Dignity' was produced and disseminated widely by the CGTS, during 2015 (CGTS 2015). These rights-based approaches to social work, seeking to counter the victimisation of those suffering unemployment and poverty as a result of the recent socioeconomic crises, have been and remain of paramount importance in empowering and upholding service users' dignity across Europe. 
Some authors have explored broad human rights-based social work models within the UK (e.g. Dominelli 2007; Cemlyn 2008a), but we believe that in order for UK social to start using these frameworks more generally, the widespread legalistic and individualised understanding of human rights in social work need to be surpassed, hence, our humble contribution to this with a discussion of the UK panorama in relation to human rights and social work.

\section{BASW's Human Rights Policy: A Starting Point?}

BASW's (2015) Human Rights Policy arguably establishes a framework for UK social workers' engagement with broader human rights approaches in professional practice. It can also be seen as aligned with broader human rights social work frameworks, and the aforementioned 'third mandate' to a human rights-bound ethical practice (Wronka and StaubBernasconi 2012: 81). The policy aims to promote and support human rights-based social work 'as defined in the international definition of social work', and 'to help social workers ... to find ways of practising that are consistent with a common commitment to be part of an international human rights profession' (BASW 2015: 4).

The policy asserts that human rights approaches involve 'increasing the ability of those with responsibility for fulfilling rights to recognise and respect human rights (for example, the NHS, local authorities, care providers)', 'empowering people to know and claim their rights' and 'understanding the specific cultural contexts in which discrimination occurs' (BASW 2015: 7). This last point, the policy specifies, 'requires analysis of the structural causes of discrimination and poverty, rather than only its symptoms, and of the impact of governmental action or inaction on communities experiencing poverty' (BASW 2015: 7). It acknowledges social workers' individual and collective obligations towards human rights and establishes that 'social workers should ask themselves, their organisations and stakeholders questions about whether practice is complying with human rights principles and whether actions are necessary and proportionate in each individual case' (BASW 2015: 19).

Moreover, it sets for social work employers obligations to ensure that social workers 'do not face discrimination or detriment arising from their advocating for the human rights of those with whom they work, including where such advocacy is contrary to the financial, reputational or other interest of the employer' (BASW 2015: 22). The policy document offers a definition and background information about human rights and social work, followed by practical guiding principles for social workers' engagement with human rights in their practice settings. The guidance is structured around the practice implications of human rights being (a) universal, (b) inalienable and (c) indivisible in character.

\section{Conclusion}

We have here sought to set out a case for a broader and richer concept of human rights in UK social work, beyond the legalistic terms in which they are presently understood. We have tried to advance this case in alternate scenarios in which we retain or replace the HRA 1998, as well as offer ethical arguments for why values that are already present in UK social work would be enriched and improved if reconceptualised as human (and therefore client and carer) rights rather than as practitioner attributes. We have also sought to set out some of what that broader concept might look like, drawing on international perspectives.

Whether or not the UK retains or replaces the HRA, the present socio-political climate means that xenophobia and nationalism are increasing, all in an austerity context of reduction and residualizing of social work services. The need for a regrounding of social work values, and the social work mission, is greater now than it perhaps has been for a decade. We humbly suggest human rights, understood in broad, rich terms, can be the basis of that regrounding. As we have stated in the introduction of this article, the discussions we have outlined are literature and opinion-based. These would benefit greatly from further empirical research on the views on the topic of a wide range of social work stakeholders in the UK.

\section{References}

Banks, S. (2006). Ethics and values in social work (3rd ed., Practical social work ed.). Basingstoke: Palgrave Macmillan.

Banks, S., Hugman, R., Healy, L., Bozalek, V., \& Orme, J. (2008). Global ethics for social work: problems and possibilities - papers from the Ethics \& Social Welfare Symposium, Durban, July 2008. Ethics and Social Welfare, 2(3), 276-290.

BASW (2014). The Code of Ethics for social work. Statement of Principles. Birmingham: British Association of Social Workers. http://cdn.basw.co.uk/upload/basw_23237-8.pdf. Accessed 7 July 2017.

BASW. (2015). BASW human rights policy. Birmingham: The British Association of Social Workers http://cdn.basw.co.uk/upload/basw_ 30635-1.pdf. Accessed 7 July 2017.

BASW (2017). Professional capabilities framework. https://www.basw. co.uk/pcf/. Accessed 12 March 2017.

BBC News (2016). Race and religious hate crimes rose $41 \%$ after EU vote. (Thursday 13 October 2016). BBC News. http://www.bbc.co. uk/news/uk-politics-37640982. Accessed 4 July 2017.

BBC News (2017). Theresa May: human rights laws could change for terror fight (Wednesday 7 June 2017) BBC News. http://www.bbc. co.uk/news/election-2017-40181444. Accessed 3 July 2017.

Bush, S. (2017) The Conservative-DUP deal is great news for the DUP, but bad news for Theresa May. (Monday 26 June 2017). The New Statesman. http://www.newstatesman.com/politics/devolution/ 2017/06/conservative-dup-deal-great-news-dup-bad-news-theresamay. Accessed 3 July 2017.

Cemlyn, S. (2008a). Human rights and gypsies and travellers: an exploration of the application of a human rights perspective to social work 
with a minority community in Britain. British Journal of Social Work, 38(1), 153-173.

Cemlyn, S. (2008b). Human rights practice: possibilities and pitfalls for developing emancipatory social work. Ethics and Social Welfare, 2(3), 222-242.

CGTS (2015). Social Rights for Dignity. https://www.youtube.com/ watch?v=YJXkdFpcDoo. Accessed 6 April 2017.

Clark, C. (2006). Moral character in social work. British Journal of Social Work, 36(1), 75-89.

Conservative Party (2014). Protecting human rights in the UK: the conservatives' proposals for changing Britain's human rights laws. https://www.conservatives.com/ /media/files/downloadable\% 20Files/human_rights.pdf. Accessed 15 March 2017.

Conservative Party (2017) Forward, together; Our plan for a stronger britain and a prosperous future. https://s3.eu-west-2.amazonaws. com/manifesto2017/Manifesto2017.pdf. Accessed 3 July 2017.

Cromarty, H. (2016) Social Work Regulation (England), House of commons library briefing paper CBP07802, 2 December 2016. http:// researchbriefings.parliament.uk/ResearchBriefing/Summary/CBP7802. Accessed 5 July 2017.

Daniel, B., Eady, S., Engstrom, S., McLenachan, J., Westwood, J. \& Yule, N. (2016) Revised standards in social work education and a benchmark standard for newly qualified social workers. Scottish Social Services Council. http://www.sssc.uk.com/about-the-sssc/ multimedia-library/publications?task=document.viewdoc\&id= 3190. Accessed 4 July 2017.

Dominelli, L. (2007). Human rights in social work practice: an invisible part of the social work curriculum? In E. Reichert (Ed.), Challenges in human rights: social work perspective (pp. 16-43). New York: Columbia University Press.

Dominelli, L. (2010). Social work in a globalizing world. Cambridge: Polity Press.

Dominelli, L. (2012). Globalisation and indigenisation: reconciling the irreconcilable in social work. In K. Lyons, T. Hokenstad, M. Pawar, Huegler, \& N. Hall (Eds.), Sage handbook of international social work (pp. 39-55). London: Sage.

EHRC (2016). What are human rights? https://www.equalityhumanrights. com/en/human-rights/what-are-human-rights. Accessed 11 June 2016.

Evans, T., \& Ayers, A. J. (2006). In the service of power: the global political economy of citizenship and human rights. Citizenship Studies, 10(3), 289-308.

Ferguson, I. (2007). Increasing user choice or privatizing risk? The antinomies of personalization. British Journal of Social Work, 37(3), $387-407$.

Ferguson, I. (2008). Reclaiming social work: challenging neo-liberalism and promoting social justice. London: Sage.

Ferguson, I., Ioakimidis, V., \& Lavalette, M. (2017). Global social work in a political context: radical perspectives. Bristol: Policy Press.

Finn, J. L., \& Jacobson, M. (2003). Just practice: a social justice approach to social work. Peosta, Iowa: Eddie Bowers Pub. Co..

Forster, K. (2016). Hate crimes soared by $41 \%$ after Brexit vote, official figures reveal. (Thursday 13 October 2016). The Independent. http:// www.independent.co.uk/news/uk/crime/brexit-hate-crimes-racismeu-referendum-vote-attacks-increase-police-figures-officiala7358866.html. Accessed 4 July 2017.

Great Britain. Elizabeth 11. Chapter 42. (1998). Human rights act 1998. London: The Stationery Office.

GSCC. (2006). Codes of practice for social care workers and employers. London: General Social Care Council.

Hatton, K. (2008). New directions in social work practice. Exeter: Learning Matters.

HCPC. (2017). Standards of proficiency for social workers in England. London: Health and Care Professions Council http://www.hpc-uk. org/assets/documents/10003B08StandardsofproficiencySocialworkersinEngland.pdf. Accessed 4 July 2017.
Healy, L. M. (2008). Exploring the history of social work as a human rights profession. International Social Work, 51(6), 735-748.

Higgins, M. (2015). The struggle for the soul of social work in England. Social Work Education, 34(1), 4-16.

House of Commons Library (2016). A British Bill of Rights? Published Wednesday, May 18, 2016. http://researchbriefings.parliament.uk/ ResearchBriefing/Summary/CBP-7193. Accessed 3 July 2017.

Huegler, N., Lyons, K., \& Pawar, M. (2012). Setting the scene. In K. Lyons, T. Hokenstad, M. Pawar, N. Huegler, \& N. Hall (Eds.), The SAGE handbook of international social work (pp. 1-34). London: Sage.

IASSW, \& IFSW (2004). Ethics in Social Work, Statement of Principles. http://www.ifsw.org/f38000032.html. Accessed 6 March 2017.

Ife, J. (2008). Human rights and social work: towards rights-based practice. New York: Cambridge University Press.

Ife, J. (2009). Human rights from below: achieving rights through community development. Cambridge: Cambridge University Press.

Ife, J. (2016). Human rights and social work: beyond conservative law. Journal of Human Rights and Social Work, 1(1), 3-8.

IFSW. (1988). Human rights, in international policy papers. Geneva: IFSW.

IFSW (2000). International Definition of Social Work. http://www.ifsw. org/f38000138.html. Accessed 6 March 2017.

IFSW, \& IASSW (2014). Global Definition of Social Work. http://ifsw. org/get-involved/global-definition-of-social-work/. Accessed 6 March 2017

IFSW-Europe. (2012). Standards in social work practice meeting human rights. Berlin: IFSW Europe http://ifsw.org/publications/standardsin-social-work-practice-meeting-human-rights/. Accessed 4 July 2017.

Ioakimidis, V. (2015). Neocolonialism and social work. In J. D. Wright (Ed.), International encyclopedia of the social \& behavioral sciences (Second ed., pp. 456-461). Oxford: Elsevier.

Ioakimidis, V., Cruz Santos, C., \& Martinez Herrero, I. (2014). International Social Work, 57(4), 285-300.

Jones, D. N., \& Truell, R. (2015). The global agenda for social work and social development: a place to link together and be effective in a globalized world. International Social Work, 55(4), 454-472.

Labour Party (2017). For the many not the few: the Labour Party Manifesto 2017. http://www.labour.org.uk/index.php/manifesto2017. Accessed 3 July 2017.

Lee (2011). Britain's child migrants. (Saturday 2 April 2011). The Guardian. https://www.theguardian.com/lifeandstyle/2011/apr/02/ britain-child-migrants-australia-commonwealth. Accessed 4 July 2017.

Liberal Democrats (2017) .Change Britain's future: Liberal Democrat Manifesto 2017. http://d3n8a8pro7vhmx.cloudfront.net/themes/ 5909d4366ad575794c000000/attachments/original/1495020157/ Manifesto-Final.pdf?1495020157. Accessed 3 July 2017.

Liberty (n.d.). Human Rights Act mythbuster. https://www.liberty-humanrights.org.uk/human-rights/what-are-human-rights/human-rightsact/human-rights-act-mythbuster. Accessed 8 March 2017.

Lorenz, W. (2016). Keynote presentation. In Paper presented at the joint social work and education conference (JSWEC) 2016. Milton Keynes: Open University.

Lundy, C. (2011). Social work, social justice, and human rights: a structural approach to practice. Toronto: Univ of Toronto Press.

Martínez Herrero, M. I. (2017). Human rights and social justice in social work education: a critical realist comparative study of England and Spain. Durham University. http://etheses.dur.ac.uk/11991/ Accessed 4 July 2017.

Méndez Fernández, A. B., Leal Freire, B., Martínez Rodríguez, M., \& Salazar Bernanrd, J. I. (2006). Aprehendiendo a respetar: La perspectiva de Derechos Humanos como elemento fundamental en la formación y práctica del trabajo social. Acciones e Investigaciones sociales, 1, 460-487. 
Milbourne, L., \& Cushman, M. (2013). From the third sector to the big society: how changing UK government policies have eroded third sector trust. Voluntas: International Journal of Voluntary and Nonprofit Organizations, 24(2), 485-508.

Northern Ireland Social Care Council (NISCC). (2015). Standards of conduct and practice for social workers. Belfast: Northern Ireland Social Care Council https://niscc.info/storage/resources/web_ optimised_91740_niscc_standards_of_conduct_and_practice_ bluepurple.pdf. Accessed 4 July 2017.

Payne, M. (2005). The origins of social work. Continuity and change. Basingstoke: Palgrave Macmillan.

Reichert, E. (2003). Social work and human rights: a foundation for policy and practice. New York: Columbia University Press.

Scottish National Party (2017) Stronger For Scotland; Manifesto 2017. https://d3n8a8pro7vhmx.cloudfront.net/thesnp/pages/9544/ attachments/original/1496320559/Manifesto_06_01_17.pdf? 1496320559. Accessed 3 July 2017.

Scottish Social Services Council (SSSC). (2016). Codes of practice for social service workers and employers: revised 2016. Dundee: Scottish Social Services Council. http://www.sssc.uk.com/aboutthe-sssc/multimedia-library/publications?task=document. viewdoc\&id=239. Accessed 4 July 2017.

Sewpaul, V. (2005). Global standards: promise and pitfalls for reinscribing social work into civil society1. International Journal of Social Welfare, 14(3), 210-217.

Sewpaul, V. (2016). The West and the rest divide: human rights, culture and social work. [journal article]. Journal of Human Rights and Social Work, 1(1), 30-39.

Sewpaul, V., \& Jones, D. (2005). Global standards for the education and training of the social work profession. International Journal of Social Welfare, 14(3), 218-230.

Smith, L. (2017). A UK Bill of Rights? http://www.abouthumanrights.co. uk/uk-bill-rights.html. Accessed 04 July 2017.

Social Care Wales. (2017). The social worker practice guidance for social workers registered with social care Wales. Cardiff: Social Care Wales https://socialcare.wales/cms assets/file-uploads/The-socialworker-April-2017.pdf. Accessed 4 July 2017.

Staub-Bernasconi, S. (2011). Human rights and their relevance for social work as theory and practice. In L. M. Healy \& R. J. Link (Eds.),
Handbook of international social work: Human rights, development and the global profession (pp. 30-36). Oxford: Oxford University Press.

Staub-Bernasconi, S. (2016). Social work and human rights — linking two traditions of human rights in social work. Journal of Human Rights and Social Work, 1(1), 40-49.

Stone, J. (2015) Human Rights Act: what is it and why does Michael Gove want to scrap the policy? (Monday 11 May 2015). The Independent. http://www.independent.co.uk/news/uk/politics/whatis-the-human-rights-act-and-why-does-michael-gove-want-toscrap-it-10240527.html. Accessed 4 July 2017.

Swinford, S. (2017). Theresa May is preparing to abandon plans for a British Bill of Rights, sources suggest. (Thursday 26 January 2017). The Telegraph. http:/www.telegraph.co.uk/news/2017/01/26/ theresa-may-preparing-abandon-plans-british-bill-rights-sources/. Accessed 4 July 2017.

Travis, A. (2016). Lasting rise in hate crime after EU referendum, figures show. (Wednesday 7 September 2016). The Guardian. https://www. theguardian.com/society/2016/sep/07/hate-surged-after-eureferendum-police-figures-show. Accessed 4 July 2017.

United Nations. (1949). Universal declaration of human rights: adopted and proclaimed by the general assembly of the United Nations on the tenth day of December 1948: final authorized text United Nations publication (Vol. Sales no: 1949 I 3). New York: United Nations Department of Public Information.

United Nations. (1994). Human rights and social work: a manual for schools of social work and the social work profession. New York and Geneva: Centre for Human Rights. United Nations.

Worley, W. (2016). Theresa May will campaign to leave the European Convention on Human Rights in 2020 election. (Thursday 29 December 2016). The Independent. http://www.independent.co.uk/ news/uk/politics/theresa-may-campaign-leave-europeanconvention-on-human-rights-2020-general-election-brexita7499951.html. Accessed 3 July 2017.

Wronka, J., \& Staub-Bernasconi, S. (2012). Human rights. In K. H. Lyons, T. Hokenstad, M. Pawar, N. Huegler, \& N. Hall (Eds.), The Sage handbook of international social work (pp. 70-84). London: Sage. 